\title{
CARACTERIZAÇÃO DE PLANTAS TRANSGÊNICAS DE TABACO (Nicotiana tabacum L.) QUE EXPRESSAM O GENE Lhcb1*2 DE ERVILHA QUANTO AOS IMPACTOS NO DESENVOLVIMENTO DOS CLOROPLASTOS E FORMAÇÃO DO FOTOSSISTEMA II
}

\section{RAQUELINE CUNHA CORDEIRO}

Dissertação apresentada à Escola Superior de Agricultura "Luiz de Queiroz", Universidade de São Paulo, para obtenção do título de Mestre em Agronomia, Área de concentração: Genética e Melhoramento de Plantas.

P I R A C I C A B A

Estado de São Paulo - Brasil

Setembro - 2004 
CARACTERIZAÇÃO DE PLANTAS TRANSGÊNICAS DE TABACO (Nicotiana tabacum L.) QUE EXPRESSAM O GENE Lhcb1 *2 DE ERVILHA QUANTO AOS IMPACTOS NO DESENVOLVIMENTO DOS CLOROPLASTOS E FORMAÇÃO DO FOTOSSISTEMA II

\section{RAQUELINE CUNHA CORDEIRO}

Engenheiro Agrônomo

Orientador: Prof. Dr. CARLOS ALBERTO LABATE

Dissertação apresentada à Escola Superior de Agricultura "Luiz de Queiroz", Universidade de São Paulo, para obtenção do título de Mestre em Agronomia, Área de concentração: Genética e Melhoramento de Plantas.

P I R A C I C A B A

Estado de São Paulo - Brasil

Setembro - 2004 


\section{Dados Internacionais de Catalogação na Publicação (CIP) DIVISÃO DE BIBLIOTECA E DOCUMENTAÇÃO - ESALQ/USP}

\section{Cordeiro, Raqueline Cunha}

Caracterização de plantas transgênicas de tabaco (Nicotiana tabacum L.) que expressam o gene $L h c b 1 * 2$ de ervilha quanto aos impactos no desenvolvimento dos cloroplastos e formação de fotossistema II / Raqueline Cunha Cordeiro. - - Piracicaba, 2004

45 p. : il.

Dissertação (mestrado) - - Escola Superior de Agricultura Luiz de Queiroz, 2004.

Bibliografia.

1. Engenharia genética 2. Fumo 3. Linhagens vegetais 4 . Melhoramento genético vegeti 5. Metabolismo fotossintético 6. Microscopia eletrônica 7. Planta transgênica

Plastídeos I. Título

CDD 633.71

\section{"Permitida a cópia total ou parcial deste documento, desde que citada a fonte - O autor"}


Aos meus pais, Adauto e Marly, às minhas irmãs, Raquel, Renata e Rudymilla e sobrinha Raphaela, por todo o amor a que me foi dado. OFEREÇO

A meu AMOR

José Ricardo Alves Santos

por toda a nossa felicidade.

DEDICO 


\section{AGRADECIMENTOS}

A Deus pela minha vida com PAZ e SAUDE.

Ao Professor Dr. Carlos Alberto Labate, pela orientação.

A Dra. Mônica Tereza Veneziano Labate por estar sempre pronta a nos ensinar sempre com muita atenção, paciência e humor.

Ao Professor Elliot Watanabe Kitajima, pela orientação e suporte nos trabalhos de microscopia.

Aos amigos do NAP/MEPA - ESALQ/USP, pela convivência e aprendizado durante o desenvolvimento desse trabalho, em especial ao Dr. Francisco André Ossamu Tanaka.

Aos amigos do laboratório de Genética Fisiológica do Departamento de Genética da ESALQ/USP, em especial á Danielle (por sua amizade em anos de convivência), Daniela (a "coisa ruim" muitos trabalhos juntas), Mayra (sempre pronta a ajudar), Joice (Rê - bordosa) e D. Palmira (a mãe de todo o laboratório).

Todas as pessoas que direta ou indiretamente participaram dessa minha conquista: David, Leandro, Livia, Inês, Érica, Fabiana, Paola, Alexander, Estebam, Luciana, Juliano, Simone, Liso, Gisele, Alex, Ana Letícia, Raphael, Karina, Eduardo, Felipe, Guillermo, Gunta, Coió, Samba, Plinio, Juliana e Gabriela. 
As minhas amigas de vida: Karem (pelas nossas longas conversas, afinal falamos super pouco e baixo), Valéria (por todos os seus ensinamentos durante todo o tempo), Fernanda (pela alegria da sua amizade), Lua (nossas psico-caminhadas) e Lília (o bicho-grilo, companheira de aventuras e longas caminhadas pela ESALQ).

Aos professores do curso de Genética e Melhoramento de Plantas da ESALQ-USP, pelos ensinamentos e abertura de novos horizontes.

A minha mãe-tia Arlete de Souza Cordeiro Hippolito, a José Carlos Hippolito, William e Júlio Antônio Cordeiro Hyppolito, por sempre estarmos juntos.

As minhas "irmãs" Roberta Sans de Negri e Rachel Teixeira Chicanelli e a minha "sobrinha" Bia, por serem minha família piracicabana. 


\section{SUMÁRIO}

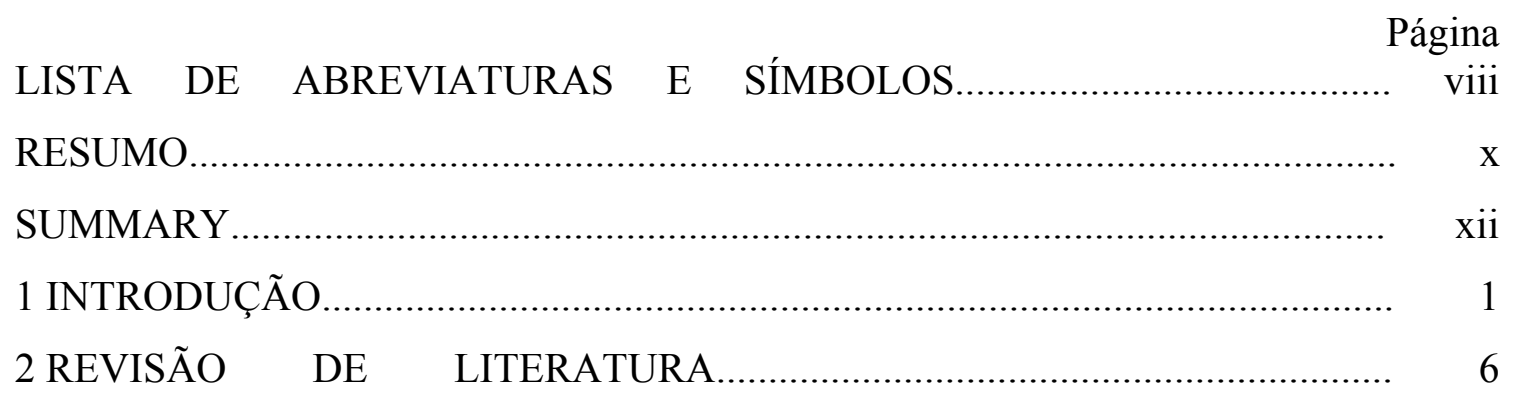

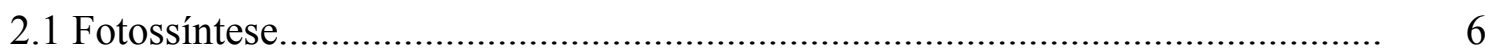

2.1.1Componentes estruturais da fotossíntese........................................ 7

2.1.2 A estrutura do fotossistema II.......................................... 9

2.2 Biogênese do cloroplasto..................................................................... 11

3 MATERIAL E MÉTODOS...................................................................... 14

3.1 Caracterização das plantas transgênicas e selvagens............... 14

3.2 Condições de cultivo...................................................................... 15

3.3 Cultivo em meio MS com 3\% de sacarose..................... 15

3.4 Coleta de material para análise anatômica de

ultraestrutura dos plastídios.................................................................... 16.

3.5 Extração de proteínas dos tilacóides e preparo das

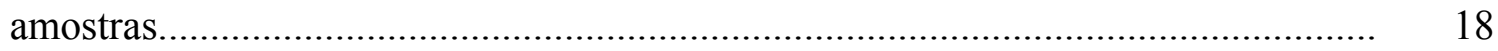

3.5.1 Eletroforese de proteínas em gel de poliacrilamida...... 19 3.5.2 Avaliação da presença das proteínas Lhcb e D1

por Western Blot..................................................................................... 20

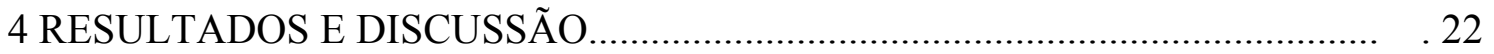


4.1 Estudo anatômico e estrutural dos cotilédones das linhagens de tabacos

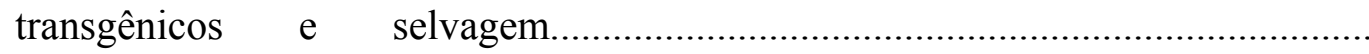

4.2 Estudo ultraestrutural de cloroplastos nos cotilédones de tabacos

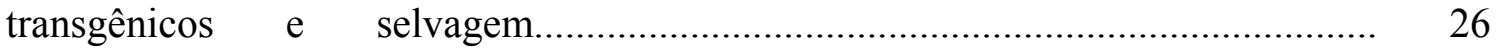

4.3 Estudo ultraestrutural dos cloroplastos nas folhas de plantas de tabacos transgênicos e selvagem cultivadas em meio de cultura MS com $3 \%$ de sacarose.

4.4 Avaliação da presença das proteínas Lhcb e D1 por

Western blot............................................................................................ 34

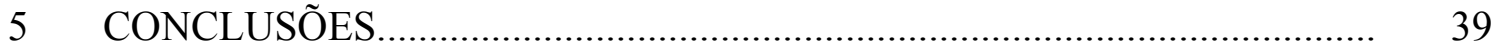

REFERÊNCIAS BIBLIOGRÁFICAS............................................................ 40 


\section{LISTA DE ABREVIATURAS E SÍMBOLOS}

$\AA$

AA

ADP

$\mathrm{CAB}$

$\mathrm{CO}_{2}$

CR

EDTA

Hepes

His

KDa

Ile

LHC

MES

Met

$\mathrm{MoCo}$

Mops- $\mathrm{NaOH}$

$\mathrm{NAD}^{+}$

$\mathrm{NADH}$

$\mathrm{NADP}^{+}$

NADPH

$\mathrm{NO}^{-}$

OAA angstrom

aminoácidos

adenosina 5-difosfato

chlorophyl a/b binding protein

gás carbônico

centro de reação

ácido tetra acético etilenodiamino

ácido N-2-hidroxietilpiperazine-N'2-etanosulfônico

histidina

kilodaltons

isoleucina

Complexo coletor de luz

ácido 2-(N-morfolino)etanosulfônico

Metionina

Molibdênio-pterina

ácido 3-(morfolino)propanosulfônico

dinucleotídeo adenina nicotinamida

dinucleotídeo adenina nicotinamida (reduzido)

dinocleotídeo adenina fosfato nicotinamida

dinocleotídeo adenina fosfato nicotinamida

(reduzido)

nitrato

oxalacetato 


$\begin{array}{ll}\text { PEP } & \text { fosfoenolpiruvato } \\ \text { PEPC } & \text { fosfoenolpiruvato carboxilase } \\ \text { 2PGA } & \text { ácido 2-fosfoglicérico } \\ \text { 3PGA } & \text { ácido 3-fosfoglicérico } \\ \text { PGK } & \text { fosfoglicerato quinase } \\ \text { Pi } & \text { fosfato inorgânico } \\ \text { PMSF } & \text { fenilmetilsulfonil fluorido } \\ \text { PS } & \text { fotossistema } \\ \text { RUBISCO } & \text { ribulose 1,5-bifosfato carboxilase/oxigenase } \\ \text { RuBP } & \text { ribulose 1,5-bifosfato } \\ \text { Ser } & \text { serina } \\ \text { SPS } & \text { sacarose fosfato sintase } \\ \text { Tris } & \text { 2-amino 2-(hidroximetil)propano 1,3-diol }\end{array}$




\section{CARACTERIZAÇÃo DE Plantas TRANSGÊnicas DE TABACO (Nicotiana tabacum L.) QUE EXPRESSAM O GENE Lhcb1*2 DE ERVILHA QUANTO AOS IMPACTOS NO DESENVOLVIMENTO DOS CLOROPLASTOS E FORMAÇÃO DO FOTOSSISTEMA II}

Autora: Raqueline Cunha Cordeiro

Orientador: Prof. Carlos Alberto Labate

\section{RESUMO}

A produção vegetal é dependente do processo fotossintético. As técnicas de biologia molecular e transformação genética de plantas trouxeram boas perspectivas para a alteração do metabolismo fotossintético. Plantas transgênicas de tabaco (Nicotiana tabacum, L.) que superexpressam o gene quimérico $L h c b 1 * 2$ de ervilha têm sido estudadas por apresentarem uma série de alterações no desenvolvimento e no metabolismo fotossintético, em relação à linhagem selvagem. Vários autores observaram mudanças morfológicas, fisiológicas, bioquímicas e adaptativas que favorecem essas plantas em diversas condições de cultivo. O objetivo desse trabalho foi o de avaliar o impacto da superexpressão desse gene na formação plastidial de plântulas de tabaco germinadas e mantidas no escuro por sete dias e depois transferidas à luz, com coletas periódicas de 0, 6, 18 e 120 horas pós-iluminação. O desenvolvimento plastidial, avaliado por microscopia 
de luz, mostra um provável adiantamento na formação dos cloroplastos dos materiais vegetais transgênicos (TR1 e TR2) em relação à selvagem (WT). A análise de ultraestrutura dos plastídios por microscopia eletrônica de transmissão, demostrou um real adiantamento na formação dos cloroplastos maduros nas duas linhagens transgênicas A análise de Western blot confimou a presença de proteínas específicas do fotossistema II (Lhcb 1-2 e D1). Este fato implica que a montagem do aparato fotossintético é antecipada nos transgênicos, assim como o desenvolvimento morfológico e estrutural observado nos plastídios. 


\section{CHARACTERIZATION OF TRANSGENIC TOBACCO PLANTS (Nicotiana tabacum L.) WHICH EXPRESS THE PEA Lhcb1*2 GENE, UPON CHLOROPLAST DEVELOPMENT AND ASSEMBLY OF THE PHOTOSSYSTEM II}

Author: Raqueline Cunha Cordeiro

Adviser: Prof. Carlos Alberto Labate

\section{SUMMARY}

The vegetal production is strictly dependent on the photosynthetic process. Techniques of molecular biology and genetic transformation of plants brought good perspectives for the alteration of the photosynthetic metabolism. Transgenic tobacco plants (Nicotiana tabacum, L.) which express the chimeric pea $L h c b 1 * 2$ gene were pbtained and presenta series of alterations on development and photosynthetic metabolism in relation to the wild type. Previous analysis have demonstrated morphological, physiological, biochemical and adaptative changes that favour these transgenic lines in various conditions of culture. The aim of this work was to evaluate the impact of the expression of this gene in the plastid formation, of tobacco seedlings. Seeds were germinated and kept in darknes for seven days, and transferred to light. The seedlings were then collected after 0, 6, 18 and 120 hours of exposure to continuous ilumination. The plastidial development evaluated by light microscopy, showed an advanced 
chloroplast formation of the transgenic lines (TR1 and TR2) in relation to the wild type (WTSR1). The ultrastructural analysis of the plastids by electronic microscopy showed, indeed on advanced formation of mature chloroplasts in the transgenic lines. The Western blot analysis confirmed the presence of two specific proteins (CAB and $\mathrm{D} 1)$, of the photosystem II. This fact implies that the assembly of the photosynthetic apparatus might occurs earlier in the transgenic lines, as well as the morphological and structural development of the plastids. 


\section{INTRODUÇÃO}

O melhoramento vegetal tem levado a grandes aumentos de produção em diversas culturas durante os tempos. Nas últimas duas décadas, um significativo aumento no rendimento das culturas tem sido obtido com auxilio das técnicas de biologia molecular e transformação genética de plantas que vieram incrementar os métodos de seleção com novas perspectivas para programas de melhoramento.

A compreensão dos aspectos físiológicos da produção de matéria seca pela cultura, associada ao efeito do meio ambiente no qual a cultura está estabelecida, permitirá avanços e ganhos em produtividade agrícola. Esses trabalhos sempre procuraram uma maior adaptação das plantas às condições adversas de cultivo. Dentro desse contexto encontra-se a importância dos estudos do processo fotossintético na produção de alimentos e fibras, pois um dos mecanismos possiveis para o aumento da produtividade das culturas é através do aumento da capacidade de assimilação de energia das plantas.

A luz, fonte de energia para as plantas, é absorvida inicialmente pelo sistema antena (LHCII) associado ao fotossistema II (PSII) nos tilacóides dos cloroplastos. As proteínas CAB ("Chlorophyll $a / b$ Binding Protein"), hoje nomeada Lhcb são os principais componentes desse sistema antena associado a clorofilas e carotenóides. 
O LHCIIb é o principal complexo proteíco e está associado a aproximadamente $60 \%$ do total de clorofila do cloroplasto.

As plantas são capazes de ajustar o tamanho do sistema coletor de luz de acordo com a luminosidade disponível para o crescimento (Anderson \& Anderson, 1988). A quantidade desses complexos determina a maior ou menor capacidade de uma planta em captar a energia solar. Em baixa luminosidade, a habilidade da planta manter boas taxas fotossintéticas é condicionada pela sua capacidade genética de aumentar a quantidade dos LHCII.

Plantas transgênicas de tabaco (Nicotiana tabacum, L.) que superexpressam o gene $L h c b 1 * 2$ de ervilha que codifica a proteina CAB tipo I (28 kDa) do LHCIIb, têm sido estudadas por apresentarem uma série de alterações no metabolismo fotossintético, além de ganho genético em relação ao material selvagem. Duas linhagens transformadas, independentemente (TR-1 e TR-2) foram selecionadas de uma série de 21 , cujos niveis endógenos da proteína $C A B$ foram os mais elevados. A seleção das plantas foi feita por análise de Northern Blot comparando-se a expressão total do gene Lhcb 1*2 (Ko et al. 1992).

A expressão constitutiva do gene Lhcb $1 * 2$, em plantas transgênicas de tabaco, quando cultivadas em condições limitantes de luz, causou uma série de efeitos pleiotrópicos que resultaram em alterações na morfologia e desenvolvimento das plantas como observado por Real (1997). Essas plantas crescem mais vigorosamente que as selvagens, possuem folhas maiores, borda continua e espaços intercelulares maiores. A análise da ultraestrutura foliar revelou a 
presença de um número maior de cloroplastos por célula, com formato preferencialmente arredondado e tamanho maior nas plantas transgênicas. Foi observado que os tilacóides das linhagens transgênicas são mais expessos (maior quantidade de granas, cerca de duas vezes). O aumento no número de cloroplastos por célula (cerca de $25 \%$ ) parece estar associado ao aumento no tamanho das células, resultando em um número menor de células por área e folhas maiores no início do desenvolvimento, que apresenta um dobramento característico (Labate, 2001).

A germinação das sementes transgênicas é precoce, ocorrendo cerca de 2 a 3 dias antes das selvagens; o hipocótilo das plântulas após 15 dias da germinação, possui o dobro do comprimento do selvagem. O tempo para atingir o florescimento também foi alterado nas plantas transgênicas (100 dias) em relação às selvagens (75 dias). Esse atraso no florescimento é conseqüência da extensão do período vegetativo, resultando em um aumento no número de folhas nas plantas transgênicas até o florescimento, cerca de duas vezes em relação à selvagem (Real, 1997).

Pinto (1999) estudando essas plantas quando cultivadas em condições de alta luminosidade verificou que as transgênicas apresentavam uma lâmina foliar mais espessa que a das plantas selvagens. As transgênicas também apresentam, tanto um menor número de células da epiderme superior por extensão foliar quanto um menor número de células do parênquima paliçádico por extensão foliar, com maior número de cloroplastos por célula. Esse resultado é 
esperado, pois as células da epiderme superior e também do parênquima paliçádico das plantas transgênicas (TR1 e TR2) são maiores, provavelmente, para comportar um maior número de cloroplastos. As células do parênquima lacunoso das trangênicas possuem espaços livres maiores quando comparadas às selvagens.

Plantas de tabaco transgênicas e selvagens mantidas por um período prolongado no escuro (21 dias), mostraram que a expressão da proteina Lhcb 1-2 de ervilha está presente e funcional nas transgênicas, mesmo após esse período de escuro, uma vez que o transgene está sob o controle do promotor constitutivo CaMV 35S. (Pinto,1999) avaliou as plantas nessas condições, quanto às diferenças fenotípicas, conteúdo de pigmentos e degradação das proteínas do LhcbII. A manutenção da transcrição proporcionou uma menor degradação das proteínas do Lhcb das transgênicas em relação às selvagens.

Esses resultados levaram à condução de um novo experimento para avaliar o impacto do transgene no desenvolvimento das plântulas. Plântulas de tabaco estioladas permaneceram no escuro por sete dias, antes de serem tranferidas à luz por 24 horas. A biossintese da clorofila nas transgênicas, ocorreu cerca de 2,5 horas após a iluminação enquanto nas selvagens iniciou-se após 7-8 horas, assim como os padrões de expressão total do gene $L h c b 1 * 2$, sendo que os transgênicos já apresentavam o transcrito na ausência de luz (Labate, 2001). 
Este fato leva à conclusão de que os transgênicos não seguem o ciclo circadiano de expressão gênica, diferentemente do que ocorre para o material selvagem, em relação à expressão desse gene endógeno. Dessa forma, os objetivos deste trabalho foram:

(i) Avaliar, por Western blot, se as plântulas de tabaco transgênicas e selvagens mantidas por sete dias no escuro estariam produzindo a proteína Lhcb 1-2;

(ii) Nessas mesmas condições, observar através de microscopia de luz e eletrônica se existe, algum estimulo à diferenciação dos proplastídios nos transgênicos na ausência de luz;

(iii) Acompanhar em períodos determinados de 0, 6, $18 \mathrm{e}$ 120 horas o desenvolvimento de proplastídeos em cloroplastos, em especial o início de formação dos tilacóides com o estímulo da iluminação;

(iv) Além de: avaliar se a sacarose influencia no desenvolvimento plastídial. 


\section{REVISÃO DE LITERATURA}

\subsection{Fotossíntese}

A luz é a fonte primária de energia que mantém a vida no planeta. O processo fotossintético que ocorre nas plantas, algas e algumas bactérias (organismos autotróficos) é essencial para a manutenção da sobrevivência das demais formas de vida (organismos heterotróficos). O processo fotossintético das plantas ocorre nos cloroplastos e resulta na liberação de oxigênio molecular e na captura de dióxido de carbono da atmosfera, que é utilizado para sintetizar carboidratos, sendo dividido segundo Pimentel, (1998) em duas fases ou reações:

1) reações luminosas: para a captação da energia luminosa e transformação desta em energia química (ATP), para as reações que absorvem energia na formação de açúcares; e em poder redutor (NADPH), para a redução do $\mathrm{CO}_{2}$ atmosférico a carboidrato, mas também para outras reações, que consomem ATP e NADPH;

2) reações ditas de escuro: que são reações enzimáticas de incorporação do $\mathrm{CO}_{2}$ atmosférico em compostos orgânicos, utilizando o ATP e o NADPH produzido nas reações luminosas.

A fotossintese é um processo muito complexo que compreende muitas reações físicas e químicas, que ocorrem de maneira 
coordenada em complexos proteícos, pigmentos e outros compostos associados a membranas.

\subsubsection{Componentes estruturais da fotossíntese}

Como já dito as reações luminosas ocorrem nos cloroplastos, em vesículas chamadas grana, formadas pela membrana dos tilacóides, onde estão os componentes dos fotossistemas, sendo estes organizados em quatro complexos supra-moleculares: fotossistema I (PSI), fotossistema II (PSII), citocromo $b 6 / f$ e ATP sintetase. Para completa função do aparato fotossintético estes apresentam assimetria definida ao longo da membrana para a realização adequada da coleta de luz e a sua distribuição, transporte de elétrons e prótons e a formação de ATP e NADPH (Anderson \& Styring, 1991).

O fotossistema II (PSII) é o local onde a molécula de água é quebrada e acontecem as reações de evolução do oxigênio (Hankamer \& Barber, 1997). O PSII está localizado preferencialmente na parte interna das membranas empilhadas do tilacóide, mas há uma pequena quantidade do complexo do PSII que se encontra nas membranas não empilhadas do estroma (Bassi et al., 1997). O PSII é responsável por muitos dos mecanismos de adaptação e proteção do aparato fotossintético em resposta às variações das condições ambientais, cujas respostas envolvem o rearranjamento das membranas dos tilacóides (Anderson \& Styring, 1991).

Do PSII o fluxo dirige-se para outro complexo protéico de membrana: o complexo do citocromo $b 6 / f$ (Hankamer $\&$ Barber , 1997). 
O citocromo $b 6 / f$ está localizado tanto nas membranas empilhadas do grana quanto nas lamelas e estroma dos cloroplastos. O complexo citocromo $b \sigma / f$ transfere elétrons do "pool" de plastoquinona para a plastocianina e então para o PSI (P700) tendo portanto, uma posição estratégica entre os dois fotossistemas (Willey \& Gray, 1988).

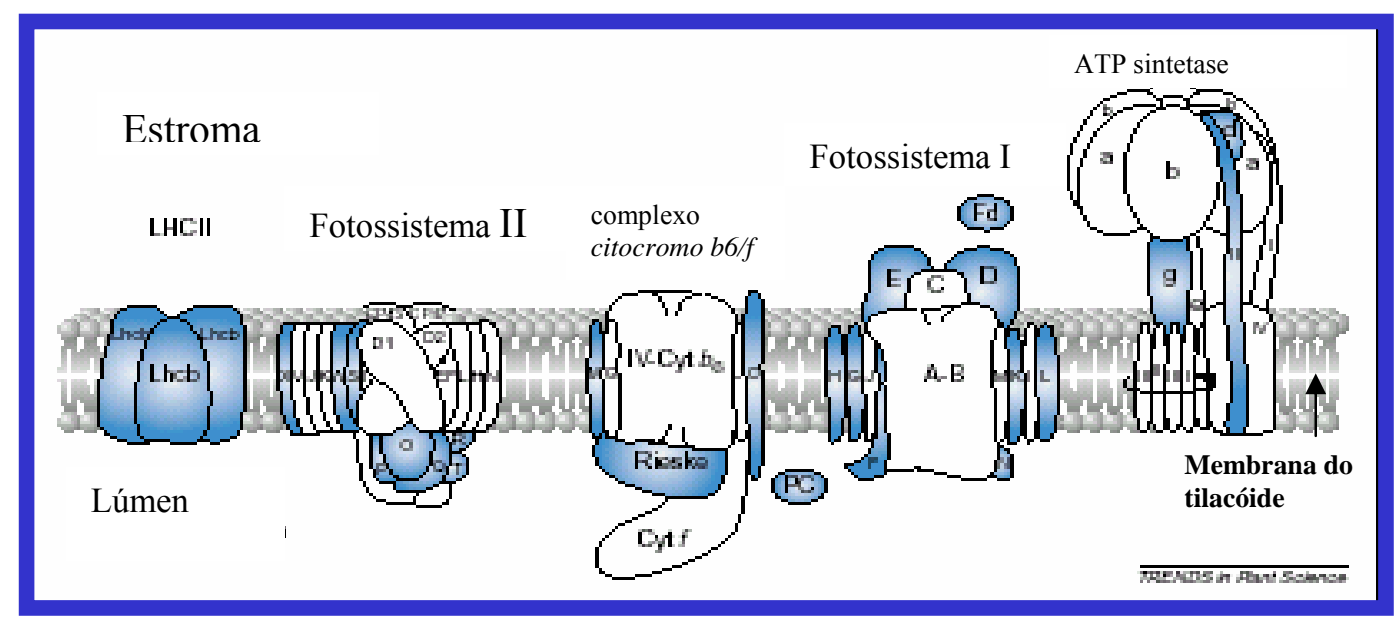

Figura 1- Complexos fotossintéticos na membrana dos tilacóides. A composição esta baseada nos dados atuais, mas a ordem dos complexos é muito arbitrária. As subunidades em azul são codifícadas no núcleo, as em branco são codificadas no cloroplasto. Figura adaptada de Dent et al. 2001

O fotossistema I (PSI) está localizado principalmente nas regiões não empilhadas da membrana dos tilacóides. O PS I, catalisa também, uma separação de cargas induzidas pela luz, de um modo basicamente similar ao fotosistema II: a luz é coletada no complexo antena. A energia da luz é transferida para uma molécula de clorofila do 
centro de reação, onde inicia-se a separação de cargas induzidas pela luz. A forma reduzida (NADPH), pode ser usada para a fixação do carbono. A clorofila do centro de reação oxidada recebe eventualmente outros elétrons até o complexo do citocromo b6/f (Hankamer \& Barber, 1997).

Por último, o complexo enzimático associado à membrana que é responsável pela sintese de ATP é chamado, fator de acoplamento ou ATP sintetase. Os cloroplastos apresentam um fator de acoplamento que consiste de dois componentes distintos, um complexo hidrofilico chamado $\mathrm{CF}_{1}$ e o complexo proteíco hidrofóbico chamado $\mathrm{CF}_{0}$ (Wettstein et al., 1995).

\subsubsection{A Estrutura do Fotossistema II}

O Fotossistema II (PS II) media a transferência de elétrons da água para a plastoquinona. Nas plantas superiores o PS II é composto de um complexo central (CCII) e um complexo coletor de luz (LHCII) (Andersson \& Styring, 1992; Chitnis \& Thornber, 1988; Thornber, 1986). O CCII atua na captação parcial da luz e na fotoquímica da separação de cargas usando o P680 como doador primário no centro de reação.

A antena acessória do PS II denominado de LHCII ("Light Harvesting Complex") é o maior componente da membrana dos tilacóides, sendo responsável por metade de sua clorofila e massas protéicas (Anderson \& Styring, 1991). Os polipeptídeos que formam o LHCII são codificados por famílias de multigenes nucleares, denominadas $L h c$ "light havesting chlorophyll $a / b$ binding protein" 
anteriormente conhecidas como genes $c a b$ ("Chlorophyll $\mathrm{a} / \mathrm{b}$ binding proteins") (Jansson et al., 1992). Análises revelaram que as seqüências primárias das apoprotéinas do LHCII indicam que estas proteínas contém três domínios na extensão das membranas dos tilacóides, com a região amino-terminal da proteína exposta ao estroma do cloroplasto e a carboxil-terminal no lúmen do tilacóide (Thornber, 1988).

A função das proteínas Lhcb é a de orientar a disposição espacial das moléculas de clorofila e carotenóides, para que a energia seja transferida para o PSII de maneira eficiente (Kuhlbrandt et al., 1994). Cerca de 200 a 300 moléculas de clorofila estão associadas a cada centro de reação (CR), formando uma unidade funcional do PSII (Horton et al., 1996). Os LHCIIs consistem de dois tipos distintos de complexos pigmento-proteína. Um deles refere-se a duas proteínas relacionadas (CP47 E CP43) que, acopladas a aproximadamente 50 moléculas de clorofila $a$, estão ligadas ao centro de reação, formando a parte central do PSII. Os outros complexos associados ao centro de reação são os complexos do LHCII, polipeptídeos de 20-30 KDa associados a clorofilas do tipo $a$ e $b$ e xantofilas. O LHCIIb é o principal complexo; possui uma estrutura trimérica e está associado a aproximadamente $60 \%$ das clorofilas do PSII. O LHCIIb é composto de polipeptídeos de 28,27 e $25 \mathrm{kDa}$, codificados pelos genes Lhcb1, Lhcb2 e $L h c b 3$, respectivamente. Suas proteínas são sintetizadas no citoplasma e depois importadas pelo cloroplasto onde sofrem processamento para serem integradas às membranas do tilacóide (Greenet al., 1991).

Essas proteínas Lhcb estão organizadas em populações proximais (25 e $28 \mathrm{kDa}$ ) e distais $(27$ e $28 \mathrm{kDa})$. Os complexos menores LHCIIa (CP29), LHCIIc (CP26) e LHCIId (CP24) são proteínas monoméricas, e estão associadas a apenas $5 \%$ do total de clorofila do 
PSII (Horton et al., 1996; Kuhlbrandt et al., 1994). Acredita-se que esses complexos têm por função ligar o centro de reação do PSII aos complexos LHCIIb. Um LHCII típico contém 5 complexos LHCIIb e 3 a 4 complexos menores, os quais formam juntos uma grande antena oligomérica na membrana dos tilacóides (Bassi et al., 1992; Jansson, 1994).

\subsection{Biogênese do Cloroplasto}

Os cloroplastos se desenvolvem a partir de proplastídios, não diferenciados, que apresentam uma membrana interna. Para a maturação dessa organela há necessidade do desprendimento das vesículas, que darão origem, provavelmente às membranas internas dos cloroplastos. Na presença de luz, os proplastídios tornam-se cloroplastos maduros. Durante a maturação, a formação das membranas internas, ocorre em fases seqüenciais. As lamelas são formadas e, posteriormente complementadas por pequenos discos achatados denominados grana. Os cloroplastos maduros, com todo o complexo de membranas dos tilacóides, contêm o aparato fotossintético (Vothknecht \& Westhoff, 2001).

A expressão de genes nucleares e plastidiais deve ser coordenada para que as proteínas do aparato fotossintético sejam produzidas em quantidade suficiente para atender as necessidades da planta em determinados ambientes. Juntamente, ocorre a biogênese da membrana dos tilacóides que é arquitetada por invaginações do envelope interno, onde ocorre o acúmulo dos complexos fotossintéticos. Essas proteínas são codificadas por genes nucleares e sintentizadas no 
citosol na forma de proteínas precursoras que possuem a extensão Nterminal (peptídio trânsito). A translocação dos precursores para dentro dos cloroplastos ocorre através de um complexo de importação localizado na membrana (Cline \& Henry, 1996).

Durante a formação das pilhas de grana, ocorre a integração do complexo coletor de luz, sendo este o responsável pela organização da lamela na membrana dos tilacóides (Gray et al., 2002).

Estima-se que as proteínas fotossintéticas formam-se em três processos distintos: 1 . biogênese dos constituintes das subunidades e seus cofatores; 2. transporte para a membrana do tilacóide e 3 . montagem com as proteínas oligoméricas (Wollman et al., 1999).

A biogênese do LHCIIb descrita em Dreyfus \& Thornber (1994) em plantas de cevada germinadas no escuro e transferidas para luz intermitente por três dias, mostraram que incialmente as proteínas do LHCIIb são importadas para o cloroplasto e se acumulam nas membranas dos tilacóides na forma monomérica, associadas a pigmentos. Posteriormente, formam os trimeros durante o desenvolvimento dos cloroplastos.

A obtenção de mutantes deficientes na biogênese do cloroplasto é uma poderosa ferramenta para o estudo de genes envolvidos em processos específicos. Muitos tipos diferentes de mutantes já foram identificados, relacionados às deficiências no desenvolvimento de plastídios e formação do tilacóide, em diferentes espécies (Jarvis et al., 2000; Kroll et al., 2001; Westphal et al., 2001).

A identificação de mutantes em mecanismos que bloqueiam estágios de biossíntese são importantes para entendermos o processo de biogênese dos cloroplastos, estas mutações ocorrem em locais 
específicos, resultando em baixa função de componentes dos plastídios, causando efeitos secundários na estrutura das macromoléculas, em componentes estruturais das membranas dos tilacóides e interferem também, nas fases da formação dos tilacóides até o total bloqueio do desenvolvimento dos mesmos (Dent et al., 2001).

Outro mecanismo para estudos da biogênese dos cloroplastos é o uso da tecnologia antisense. Wan et al., (1998) foram os primeiros a demostrar a importância das proteínas LHCs para a biogênese do cloroplasto. Nesse estudo observaram que plantas transgênicas que expressam o cDNA que codifica uma proteína do sistema de importação ( $\mathrm{CPE}$, "chloroplast processing enzyme"), apresentando uma redução da importação da proteína do LHCIIb que resulta na diminuição de $25 \%$ do número de cloroplastos por célula. 


\section{MATERIAL E MÉTODOS}

\subsection{Caracterização das plantas transgênicas e selvagens}

Sementes de plantas transgênicas de tabaco (Nicotiana tabacum), variedade Petit Havana SR1, obtidas por transformação genética de discos foliares via Agrobacterium tumefaciens recombinante, ou seja, o gene de interesse ligado ao gene de resistência à canamicina (Bevan, 1984; citado em Brito, 2001), foram utilizados nesse estudo.

O gene quimérico constituí-se de uma fusão da seqüência de DNA que codifica a porção madura da proteína CAB do gene $L h c b 1 * 2$ de ervilha e do peptídio trânsito da subunidade menor da Rubisco ( $r b c S$ ), associado a uma sequência de 30 pares de bases da região 5' não traduzida do DNA à frente da região codificadora do peptídio trânsito como um "enhancer" de tradução. A expressão do transgene foi dirigida pelo promotor 35S do vírus do mosaico da couve-flor, e os sinais de terminação da transcrição foram originados do gene $L h c b 1^{*} 2$ de ervilha. 


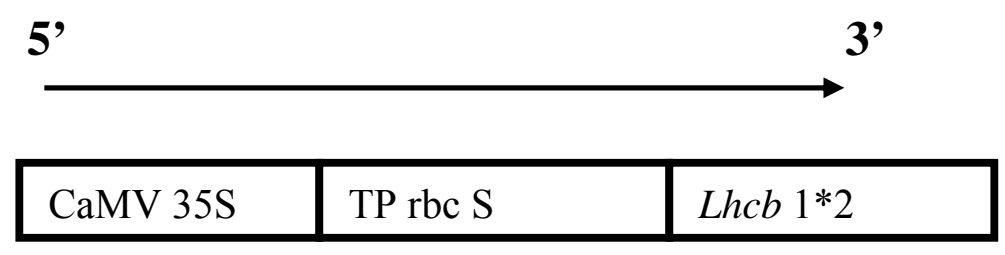

Figura 2 - Representação esquemática do cassete de expressão inserido no material transformado. A seta indica o sentido da transcrição

\subsection{Condições de cultivo}

As sementes de tabaco transgênico (TR1 e TR2) e da linhagem parental selvagem (WT) foram germinadas em caixas plásticas embrulhadas em papel alumínio, contendo papel de filtro umidecido com água destilada. Essas sementes foram postas a germinar em câmara de germinação à temperatura de $25^{\circ} \mathrm{C}$ e fotoperíodo de 16 horas de luminosidade e 8 horas de escuro. Após uma semana o material vegetal estiolado foi mantido sob luz constante por um periodo de 120 horas, com coletas periódicas nos intervalos de 0, 6, 18 e 120 horas de luminosidade. Esse material vegetal foi usado para amostras de microscopia eletrônica e de luz, e também para análise da presença de proteinas via Western blot.

\section{3 Cultivo em meio MS com $3 \%$ de sacarose}

Algumas sementes dos materiais vegetais transgênicos (TR1 e TR2) e a testemunha (WT) foram esterilizadas em etanol 70\% e lavadas em hipoclorito de sódio 1\%, contendo Tween 20 (0.05\%), por 10 minutos, 
sob agitação para posterior cultivo em meio de cultura MS (Murashige \& Skoog, 1962), contendo 3\% de sacarose.

\section{4 Coleta do material para análise anatômica de ultraestrutura dos plastídios}

As análises anatômicas, foram feitas utilizando-se os cotilédones das plântulas estioladas coletadas nos períodos de 0, 6, 18 e 120 horas de iluminação, além do material vegetal do experimento, em que as plântulas foram cultivadas no escuro em meio de cultura suprido com $3 \%$ de sacarose, seguindo-se o protocolo padrão de processamento de amostras foliares, do NAP/MEPA - ESALQ/USP.

As amostras foram fixadas para preservar integralmente a estrutura foliar e emblocadas em resina para permitir o seccionamento e montagem dos cortes em telas para a observação.

O material coletado foi imediatamente transferido para tubos de eppendorf contendo fixador (glutaraldeído 2,5\%, paraformaldeído $2,5 \%, \mathrm{CaCl}_{2}$ 0,001M e tampão Cacodilato $0.05 \mathrm{M} \mathrm{pH} 7.0$ ) onde foram mantidas por pelo menos uma hora à temperatura ambiente.

Terminada a fixação, as amostras foram lavadas três vezes em tampão Cacodilato $0,05 \mathrm{M}$, por 10 minutos cada lavagem. A pósfixação em tetróxido de ósmio $\left(\mathrm{OsO}_{4}\right)$ 1\% em tampão Cacodilato 0,05M na proporção de 1:1 à temperatura ambiente, por uma hora. Em seguida, as amostras foram lavadas com água destilada ( 3 banhos de 5 minutos cada) e então adiciona-se acetato de uranila 0,5\% para fazer a constratação en bloc, mantendo-se em geladeira por aproximadamente 16 horas. As amostras já tratadas com $\mathrm{OsO}_{4}$ e acetato de uranila foram lavadas com água destilada, sendo então seguida por uma desidratação em série de acetona a 30\%, 50\%, 70\% e 90\% por 10 minutos cada e os 
três banhos finais em acetona $100 \%$ para o início da infiltração. A primeira infiltração foi feita em meio contendo acetona $100 \%$ e resina Spurr (proporção de 1:1) Spurr, (1969), à temperatura ambiente por um tempo mínimo de 4 horas.

A resina tipo Spurr "Soft" é preparada com proporções específicas dos seguintes produtos: ERL 4206 (dióxido de vinil ciclohexano); DER 736 (diglicidil éter); NSA (anidrido noneil succínico) e DMAE (dimetilaminoetano) e terminado o tempo de infiltração, o meio foi descartado, adicionado um outro contendo apenas o Spurr puro "soft", às amostras foram mantidas à temperatura ambiente, sob agitação, por aproximadamente 16 horas.

Após esse período as amostras que estivessem no fundo dos tubos eppendorf $\mathrm{e}$ as respectivas etiquetas de identificação foram transferidas para os moldes e preenchidas com Spurr puro "soft". A polimerização ocorreu, em estufa a $70^{\circ} \mathrm{C}$, por $48-72$ horas. Os cortes das secções foram feitos em ultramicrótomo Reichert Ultracut E (Leica).

As secções para microscopia de luz foram cortadas em secções semi-finas de 1-2 $\mu \mathrm{m}$ e coradas com azul de toluidina $1 \%$ e então observadas em microscópio óptico (Olympus BX40) e fotografadas em aumentos de 1000X.

Após confirmada a presença do material desejado, procedeuse a obtenção dos cortes ultrafinos ao micrótomo, usando navalhas de vidro ou de diamante. Os cortes aproveitáveis foram os de espessura de no máximo $100 \mathrm{~nm}$.

As secções foram contrastadas por 10 minutos, em solução aquosa de acetato de uranila a cerca de $3 \%$ e citrato de chumbo, antes da visualização. 
As secções devidamente preparadas foram então analizadas no microscópio eletrônico de transmissão MET Zeiss EM 900, sendo as imagens gravadas em diferentes aumentos.

\section{5 Extração das proteínas dos tilacóides preparo das amostras}

As amostras de proteínas foram extraídas de plântulas cultivadas em caixas plásticas, coletadas em períodos de 0, 6, 18 e 120 horas pós-iluminação contínua $\left(30 \mu \mathrm{mol} \cdot \mathrm{m}^{-2} \cdot \mathrm{s}^{-1}\right)$, com o objetivo de detectar-se, através de anticorpos específicos a presença das proteínas Lhcb e D1, ambas do fotossistema II.

Para tal objetivo, procede-se de acordo com a metodologia descrita em Bassi et al (1985), a maceração do material vegetal em cadinho com nitrogênio líquido e a adição de aproximadamente $10 \mathrm{ml}$ do tampão de extração: tricina $0.1 \mathrm{M} \mathrm{pH} 7.8$, 0.4M sorbitol, 200 $\mu \mathrm{M}$ PMSF (fluoreto de fenilmetilsulfonila), $1 \mathrm{mM}$ benzamidina e $5 \mathrm{mM}$ ácido aminocapróico $\left(4^{\circ} \mathrm{C}\right)$, o material foi filtrado em folha Miracloth (Calbiochem). Procedeu-se uma centrifugação de 10 minutos à $1.400 \mathrm{~g}$ à $4^{\circ} \mathrm{C}$.

O “pellet" foi então ressuspendido em tampão Hepes 25mM(N-[2-Hidroxietil]piperazine-N'-[ácido 2-etanosulfato]) $\mathrm{pH}$ 7.5,

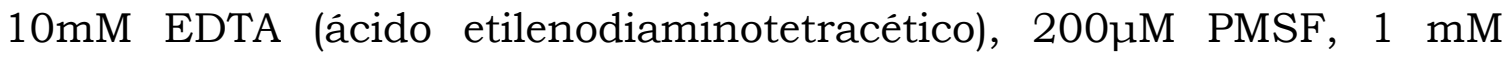
Benzamidina e $5 \mathrm{mM}$ ácido aminocapróico. e procedeu-se a duas centrifugaçôes por 10 minutos a $4^{\circ} \mathrm{C}$ com rotação de $10.000 \mathrm{~g}$ para o

rompimento dos cloroplastos e liberação das membranas tilacóide, sempre descartando-se o sobrenadante. Ao "pellet" final, adicionou-se 2 
$\mathrm{ml}$ do tampão Hepes 10mM pH 7.5, 1mM EDTA e 50\% de Glicerol, congelando-o em nitrogênio liquido, seguindo de armazenamento a $-80^{\circ} \mathrm{C}$ para posterior uso.

A clorofila foi determinada pelo método de Porra et al. (1989), citado em Brito (2001), no qual a utilizando acetona 80\% (tamponada com carbonato de sódio). Após essa reação, determinou-se a concentração das amostras via espectrômetro com base na densidade óptica a $595 \mathrm{~nm}$.

Após a quantificação da clorofila as amostras foram então centrifugadas por 2 minutos a $14.000 \mathrm{~g}$ à $4^{\circ} \mathrm{C}$ e ressuspendidas em $50 \mathrm{mM}$ de $\mathrm{Na}_{2} \mathrm{CO}_{3}$ e $50 \mathrm{mM}$ de DTT, na concentração final de $1 \mu \mathrm{g}$ clorofila/ $\mu 1$. Em seguida as amostras foram agitadas em "Vortex" e adicionado $\operatorname{SDS}(1,5 \%)$ e sacarose (concentração final 10\%). As amostras foram desnaturadas por 1 minuto à temperatura de $100^{\circ} \mathrm{C}$. Ao final uma nova aliquota foi retirada para determinar a concentraçõa final de clorofila. As amostras foram então carregadas em géis para a eletroforese.

\subsubsection{Eletroforese de proteínas em gel de poliacrilamida}

A separação das proteínas foi feita em gel desnaturante de poliacrilamida $(12 \%$ de acrilamida), e $0.06 \%(\mathrm{v} / \mathrm{v})$ de persulfato de amônio ("High-Tris" SDS/Page). O gel para aplicação das amostras foi feito com 4\% de acrilamida, $0.125 \mathrm{M}$ Tris $\mathrm{pH} 6.8,0.006 \%(\mathrm{v} / \mathrm{v})$ de Temed e $0.06 \%$ de persulfato de amônio. O tampão de corrida superior: $50 \mathrm{mM}$ Tris / 190mM glicina, 0.1\% de SDS (dodecil sulfato de sódio). O tampão de corrida inferior utilizado foi o mesmo, porém sem SDS. 
As amostras foram aplicadas e a corrida foi feita à temperatura ambiente por aproximadamente 2-3 horas para separação das proteínas, inicialmente a $50 \mathrm{~V}$ até a entrada das proteínas no gradiente, sendo então mantido a $80 \mathrm{~V}$, para as duas placas de mini-gel (sistema Mini-protean II, Bio-Rad).

\subsubsection{Avaliação da presença das proteínas Lhcb e D1 por Western Blot}

Após corrida do gel procedeu-se a transferência das proteínas por corrente transversal do gel para a membrana de PVDF, e sobre essa membrana fez-se as reações imunoquímicas, utilizando-se os anticorpos específicos para as proteínas Lhcb e D1. Por este método, proposto por Towbin. et al. (1979) verificou-se a presença das proteínas.

Preparou-se o tampão de transferência: $49 \mathrm{mM}$ de tris, 39 $\mathrm{mM}$ de glicina, $20 \%$ de metanol, $\mathrm{pH}$ 9.2. A membrana de PVDF foi cortada de um tamanho levemente maior que o gel. O gel foi lavado duas vezes com o tampão de transferência, por 10 minutos e a membrana de PVDF também foi lavada com Metanol.

A montagem da transferência foi feita com o "Semi-dry Transfer Cell" (Bio-Rad): 3 pedaços de papel de filtro, Gel, membrana de PVDF, 3 pedaços de papel de filtro. A corrida foi feita a 30 volts por 1012 horas à $4^{\circ} \mathrm{C}$. Ao final da transferência coloca-se a membrana de PVDF no tampão TBS-T: $1 \mathrm{M}$ de Tris, $\mathrm{pH}$ 7.5; 29,22 g de NaCl; 0,5 ml de Tween20 para preparo de 1 litro de Tampão.

Após a transferência os procedimentos para o Western Blot podem ser listados: 
1. Lavar a membrana de PVDF com a solução bloqueadora ("Blocking Buffer": TBS-T $+5 \%$ leite desnatado) por 1 hora a $37^{\circ} \mathrm{C}$.

2. Retirar a solução bloqueadora e adicionar o anticorpo primário em $15 \mathrm{ml}$ ("Blocking Buffer"). Incubar por 1hora a $37^{\circ} \mathrm{C}$ sob agitação.

3. Retirar o anticorpo primário, lavar a membrana 3 vezes com a solução bloqueadora, em intervalos de 10 minutos a $37^{\circ} \mathrm{C}$, sob agitação.

4. Após as lavagens, adicionar o segundo anticorpo conjugado à fosfatase alcalina, em $15 \mathrm{ml}$ da solução bloqueadora. Incubar por 1 hora a $37^{\circ} \mathrm{C}$, sob agitação.

5. Lavar a membrana com a solução bloqueadora (sem anticorpo) 3 vezes em intervalos de 10 minutos a $37^{\circ} \mathrm{C}$, sob agitação.

6. Proceder a ultima lavagem com a solução TBS-T (sem o leite desnatado) para a retirada de todo o excesso de proteína do leite. Realizar de 2-3 lavagens em intervalos de 5 minutos á $37^{\circ} \mathrm{C}$.

7. Colocar a membrana em saco plástico e retirar todo o excesso de solução TBS-T com o uso de uma régua.

8. Adicionar a solução luminescente (ECL Plus Western Blotting Detection Reagents - Amershan Biosciences). Incubar por 5 minutos. Retirar o excesso de solução luminescente com a ajuda de uma régua. Selar o saco plástico e proceder à revelação com chapa de Raio X. 


\section{RESULTADOS E DISCUSSÃO}

\subsection{Estudo anatômico e estrutural dos cotilédones das linhagens de tabacos transgênicos e selvagem}

As análises comparativas de morfologia e anatomia dos cotilédones das plantas transgênicas (TR1 e TR2) e das plantas selvagens mostraram a existência de diferenças entre os genótipos quando esses foram submetidos à luz contínua por 120 horas.

A figura 3 mostra os cortes de secções transversais dos genótipos selvagem (A e B), transgênico TR1 (C e D) e TR2 (E e F) respectivamente no tempo zero e seis horas de luz. O material transgênico apresenta uma maior quantidade de proplastídios em relação ao selvagem. Nesse período de iluminação estima-se que a biogênese do cloroplasto esta sendo induzida com o início da iluminação, mas o tilacóide se torna fotoquimicamente competente com o início do desenvolvimento estimulado pela luz (Vothknecht et al., 2001).

Há uma indicação de que a maturação dos plastídios ocorre de forma antecipada nas linhagens transgênicas como pode ser visto na figura 4; após 18 horas de iluminação, as transgênicas já apresentam plastídios com formato conchiforme enquanto a selvagem ainda se apresenta arredondado (Carvalho \& Recco-Pimentel, 2001). Já após 120 horas de 


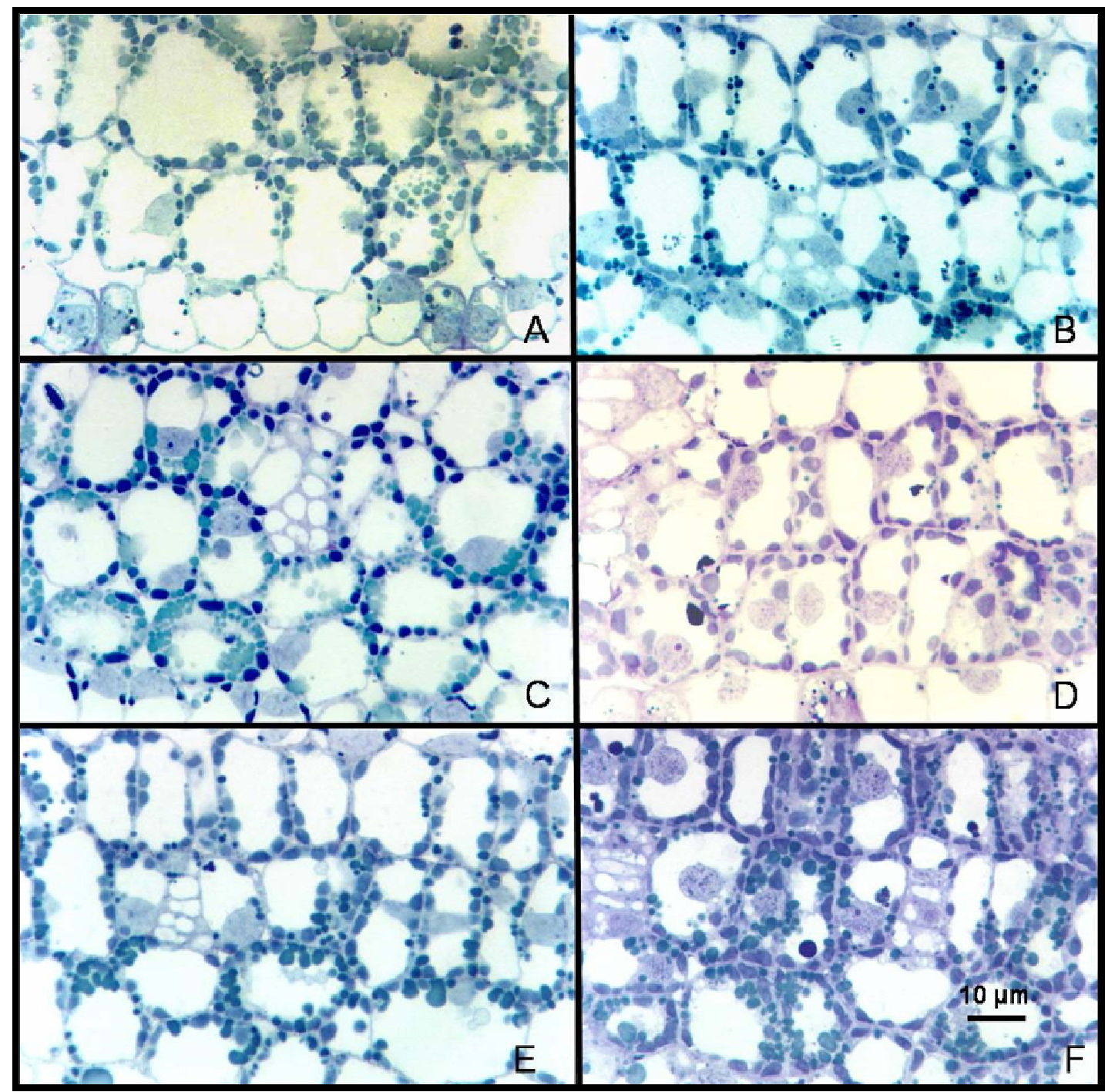

Figura 3 - Secções transversais de cotilédones de tabaco. Plantas selvagens (WT): A (0 hora) e B (6 horas).Transgênicas TR1: C (0 hora) e D (6 horas). Transgênicas TR2: E (0 hora) e F (6 horas). Coloração: Azul de Toloidina. Aumento: 1000X 


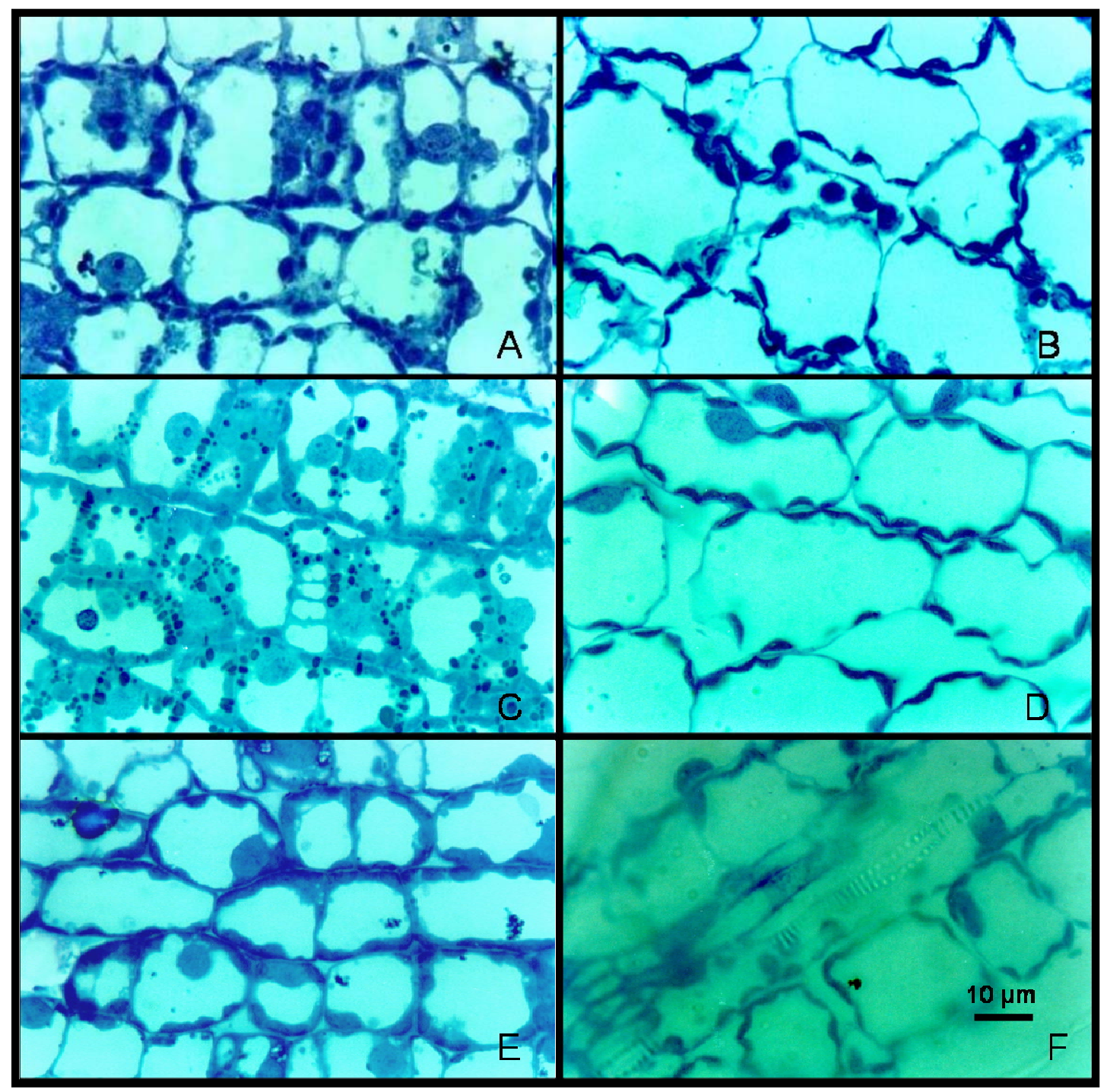

Figura 4 - Secções transversais de cotilódenes de tabaco. Plantas selvagens (WT): A (18 horas) e B (120 horas). Transgênicas TR1: C (18 horas) e D (120 horas). Transgênicas TR2: E (18 horas) e F (120 horas). Coloração: Azul de Toloidina. Aumento 1000X 
iluminação, todos os genótipos parecem estar em fase final de formação dos cloroplastos, o que será confirmado com as análises ultraestruturais.

Quando Pinto (2000) estudou essas plantas já adultas, cultivadas em alta luminosidade, observou um aumento no número de cloroplastos por célula nas transgênicas (TR-1 e TR-2) quando comparadas as selvagens (WT) sugerindo que a superexpressão do gene Lhcb $1 * 2$, ainda não sabendo de que forma altera o processo de biogênese do cloroplasto, como ficou confirmado também neste estudo com "seedlings". Wan et al. (1998), introduziu um antisense CPE (Chloroplast processing enzyme) que alterou a montagem do LHCP (Light-havesting chlorophyll binding protein) que resultou em folhas clorotícas e um atraso no desenvolvimento de brotos e raizes. Ainda houve uma redução no número de cloroplastos em $25 \%$, quando comparados ao controle, a ultraestrutura dos cloroplastos, mostrou um grande acúmulo de amido, no interior dos plastídios, provando assim a importância do Complexo coletor de Luz para o normal desenvolvimento dos plastídios. Kroll et al. (2001), analisaram mutantes de Arabidopsis thaliana quanto aos impactos causados pela deficiência do gene VIPP1 (vesicle-inducing protein in plastids 1), que leva à não produção da proteína hidrofílica que funciona na membrana interna dos tilacóides, sendo esta essencial na manutenção e organização da membrana do tilacóide. Para tal confirmação destas questões, esses autores ao analisarem um distúrbio no transporte de elétrons na fotossíntese dessas plantas, procederam então uma análise da ultraestrutura dos cloroplastos para então observarem essa mutação fenotípicamente. Observaram então cloroplastos sem organização lamelar, provando assim que a deficiência no gene VIPP1 causa alterações no desenvolvimento plastídial. 
Para a continuidade desses estudos procedeu-se então as análises ultraestruturais dos plastídios das plantas transgênicas (TR-1 e TR-2) e selvagem (WT), para um maior entendimento do que estaria ocorrendo no interior dos proplastídios e sua maturação em cloroplastos.

\subsection{Estudo ultraestrutural de cloroplastos nos cotilédones de tabacos transgênicos e selvagem.}

Os estudos comparativos da ultraestrutura dos cloroplastos dos cotilédones das plantas transgênicas (TR1 e TR2) e selvagens (WTSR1), mostraram que há um adiantamento no desenvolvimento dos proplastídios em cloroplastos maduros, no material vegetal transgênico, tanto para o caso da TR1 quanto para a TR2, em relação a selvagem.

A figura 5 mostra imagens de microscopia eletrônica de transmissão com 0 hora de luz o material selvagem (A): apresenta nesse caso os proplastídios característicos: forma arredondada e sem a presença do sistema lamelar típico (Cooper, 2001). Já nos transgênicos está havendo o início da sintese de membranas que se organizaram no sistema lamelar típico dos cloroplastos e estes estão tomando um formato mais conchiforme (Carvalho \& Recco-Pimentel, 2001).

Vothknecht et al. (2001) descreve a formação da membrana tilacóide, quando no início da formação não há diferenciação dos plastídios, observando-se apenas o envelope interno e o desenvolvimento das estruturas internas da membrana. Com o estímulo da iluminação, inicia-se a formação da membrana tilacóide que é arquitetada por invaginações da membrana interna, como pode ser observado após 18 horas de iluminação (Figura 6) o material selvagem apresenta seus plastídios ainda em desenvolvimento. A seta em (A) aponta a presença 
da estrutura semicristalina que desenvolve o sistema lamelar típico (Carvalho \& Recco-Pimentel, 2001), em (B) um detalhe do desenvolvimento do sistema de lamelas. Já nas transgênicas o desenvolvimento do cloroplasto está mais adiantado com formato conchiforme, a estrutura semicristalina com a presença do sistema de lamelas e a formação de pilhas de grana. Em (E) a seta aponta gotículas de amido em TR2. 


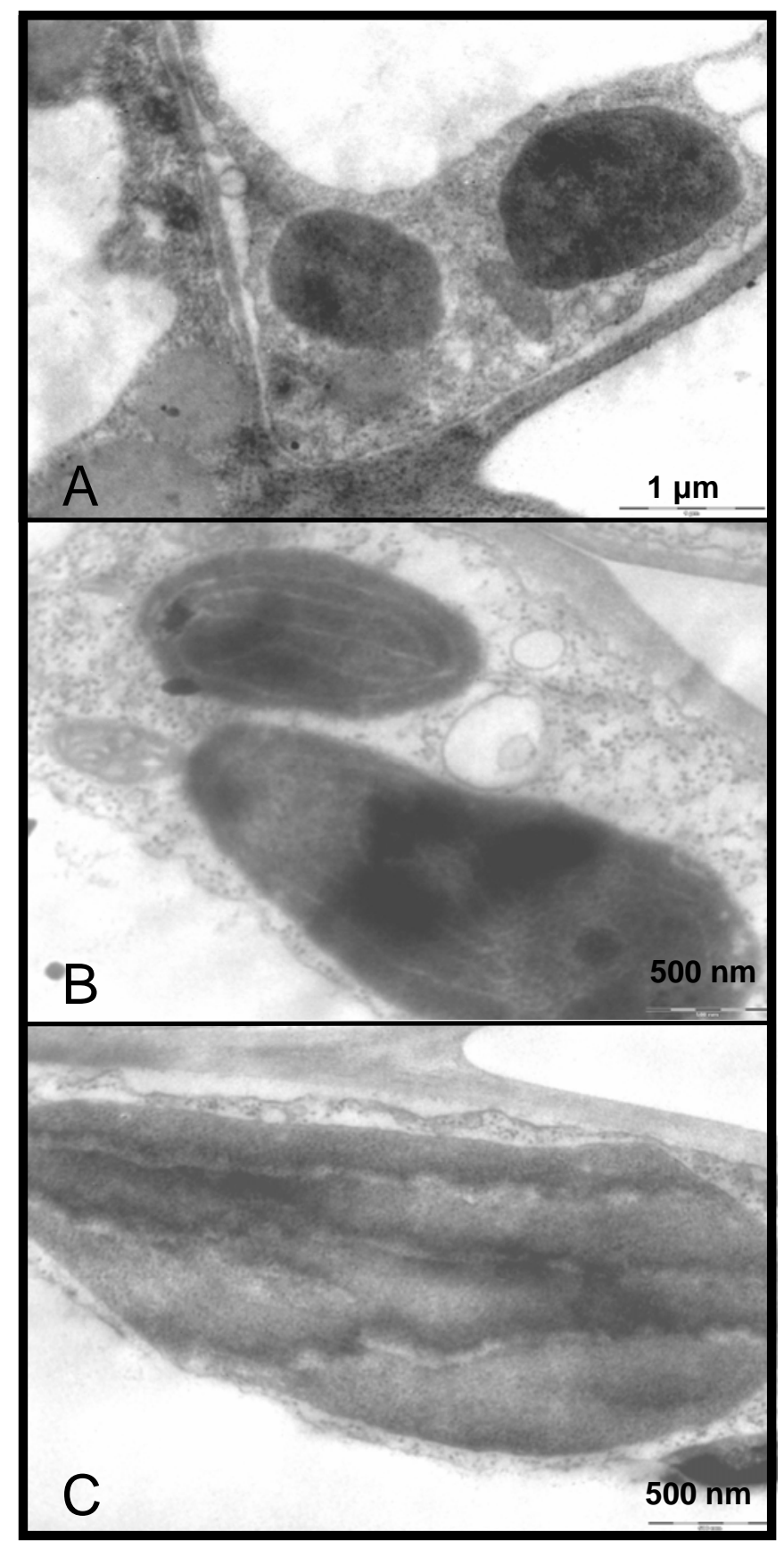

Figura 5 - Ultraestrutura dos cloroplastos de cotilédones de tabaco com 0 hora de iluminação. Plantas selvagens WT (A); Transgênicas TR1 (B) e TR2 (C) 


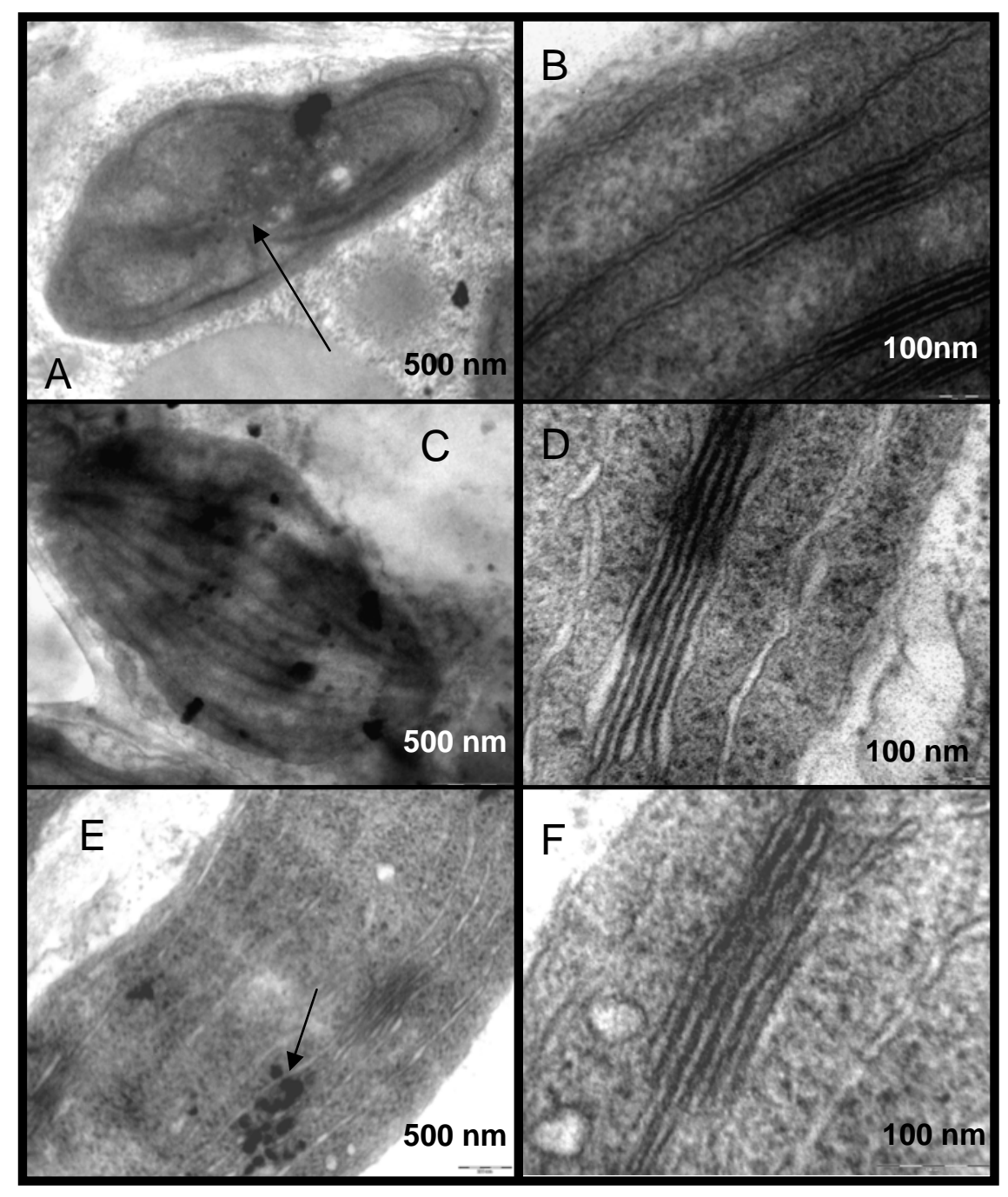


Figura 6 - Ultraestrutura dos cloroplastos de cotilédones de tabaco com 18 horas de iluminação. Plantas selvagens WT (A e B); Transgênicas TR1 (C e D) e TR2 (E e F)

O maquinário do cloroplasto é muito dinâmico na membrana do tilacóide, rápidas adaptações a condições de luz são observadas por movimento de proteínas, em especial as do complexo coletor de luz (Vothknecht, at al. 2001). Já, para as adaptações de longo prazo são requeridas novas sinteses e manutenção das membranas tilacóides já existente, assim como o desenvolvimento de novos cloroplastos a partir do envelope interno, como pode-se observar um aumento de estruturas plastídiais nas imagens de microscopia de luz (figura 4)

O final do desenvolvimento plastidial no material selvagem (WT) pode ser visto na figura 7 (A), após 120 horas de iluminação. Enquanto que os trangênicos já apresentam cloroplastos maduros Figura 7 (B e C). Vothknecht et al. (2001) descreve a maturação do cloroplasto numa intensiva formação de membranas tilacóide, ocorrendo simultaneamente o acumulo dos complexos fotossintético, esses componentes que são codificados no núcleo e importados para o cloroplasto, mais tarde, o desenvolvimento do sistema tilacóide continua com a formação das pilhas de grana (figura 7: B e C). Simidjiev et al. (2000), concluíram que o complexo coletor de luz junto com os monogalactosil diacilglicerol (lipídio da membrana) são responsáveis pela organização lamelar na membrana tilacóide. 


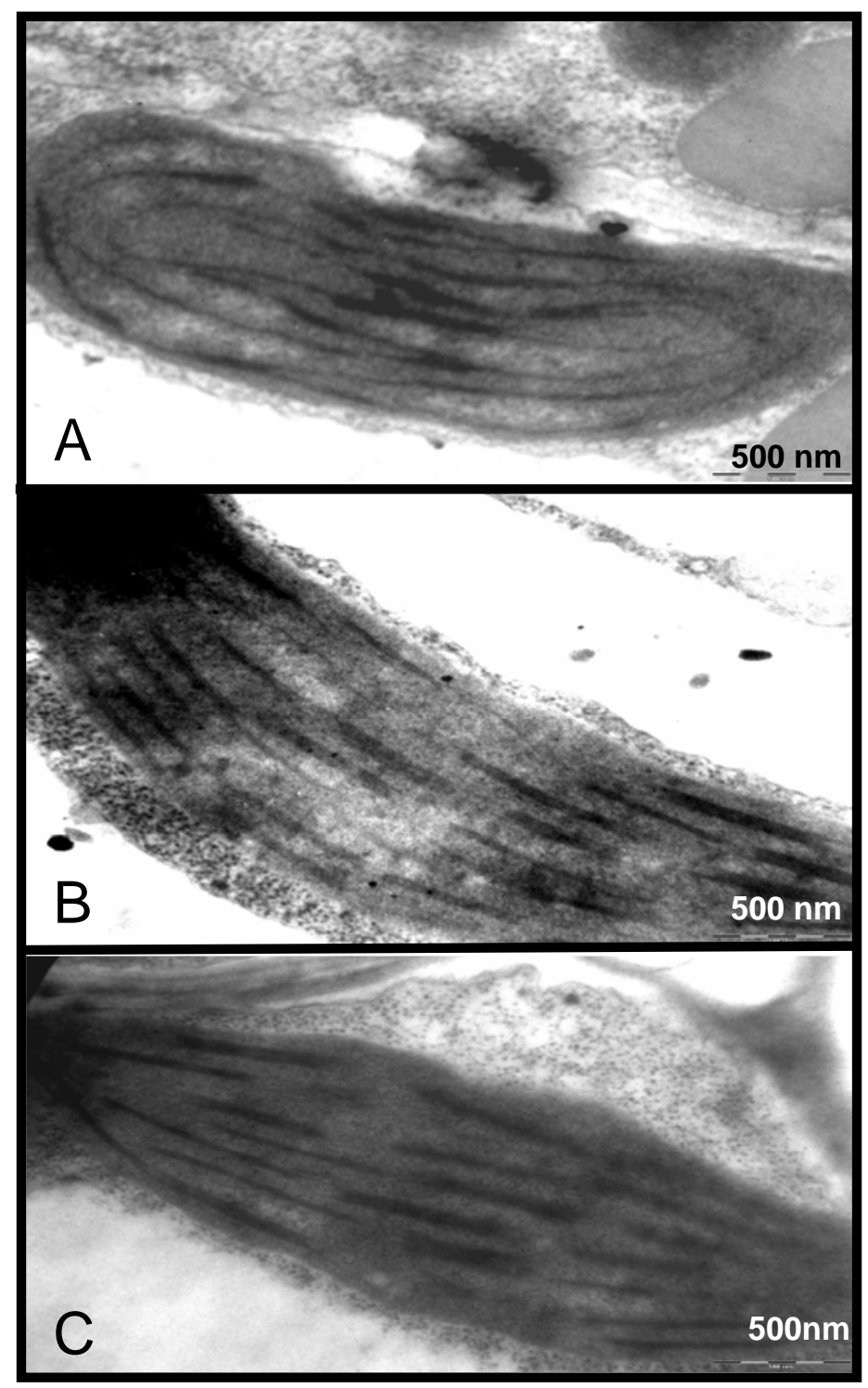

Figura 7 - Ultraestrutura dos cloroplastos de cotilédones de tabaco com 120 horas de iluminação. Plantas selvagens WT (A); Transgênicas TR1 (B) e TR2 (C) 


\subsection{Estudo ultraestrutural dos cloroplastos nas folhas de plantas de tabacos transgênicos e selvagem cultivadas em meio de cultura MS com 3\% de sacarose.}

Este experimento foi delineado com o objetivo de avaliar se o fornecimento de carboidrato seria responsável pela antecipação do desenvolvimento dos proplastídios. Para que tais resultados fossem alcançados procedeu-se a analise da ultraestrurura dos proplastídeos cultivados em presença de sacarose (3\%) e na ausência de luz.

Vários fatores podem vir a controlar as relações fonte-dreno e seus efeitos sobre a fotossintese, sintese de sacarose, transferência e utilização dos assimilados (Mitra et al. 1993). A triose-fosfato (TP), um dos primeiros produtos da fixação do $\mathrm{CO}_{2}$ pode ser exportada para o citosol para iniciar a síntese de sacarose ou pode permanecer no cloroplasto para a sintese de amido.

A expressão constitutiva do gene Lhcb $1 * 2$ que promove um aumento do sistema antena do fotossistema II (LHCII) que favorece o maior acumulo de carboidrato nessas plantas como já verificado por Real (1997). Pinto (2000) observou que a quantidade de carboidratos totais (amido + sacarose) é maior nas plantas transgênicas, em relação ao selvagem.

Como apresentado na Figura 8, a presença da sacarose em meio de cultura não causou um efeito de forma que o selvagem tivesse um adiantamento no desenvolvimento, como o apresentado pelas linhagens transgênicas. A planta selvagem continua a apresentar proplastídios típicos, com formato arredondado e sem a formação lamelar, mesmo na presença de sacarose em meio de cultivo. As transgênicas (TR1 e TR2) apresentam um desenvolvimento mais adiantado, com a formação lamelar já tomando o interior do plastídio. É 
interessante notar em $(\mathrm{F})$, um detalhe da estrutura semicristalina que sintetiza membranas que se organizam no sistema de lamelas típico no interior dos cloroplastos maduros (Carvalho \& Recco-Pimentel, 2001).

Como não há um adiantamento significativo no desenvolvimento plastídial. Nesse caso não foi o fornecimento de carboidrato que levou ao adiantamento da formação do cloroplasto, Vothknecht et al. (2001) descreve a luz como o estímulo necessário a diferenciação dos plastídios, mas para se confirmar, ainda são necessário estudos próximos, nos quais ocorras o fornecimento de carboidrato e luz. 


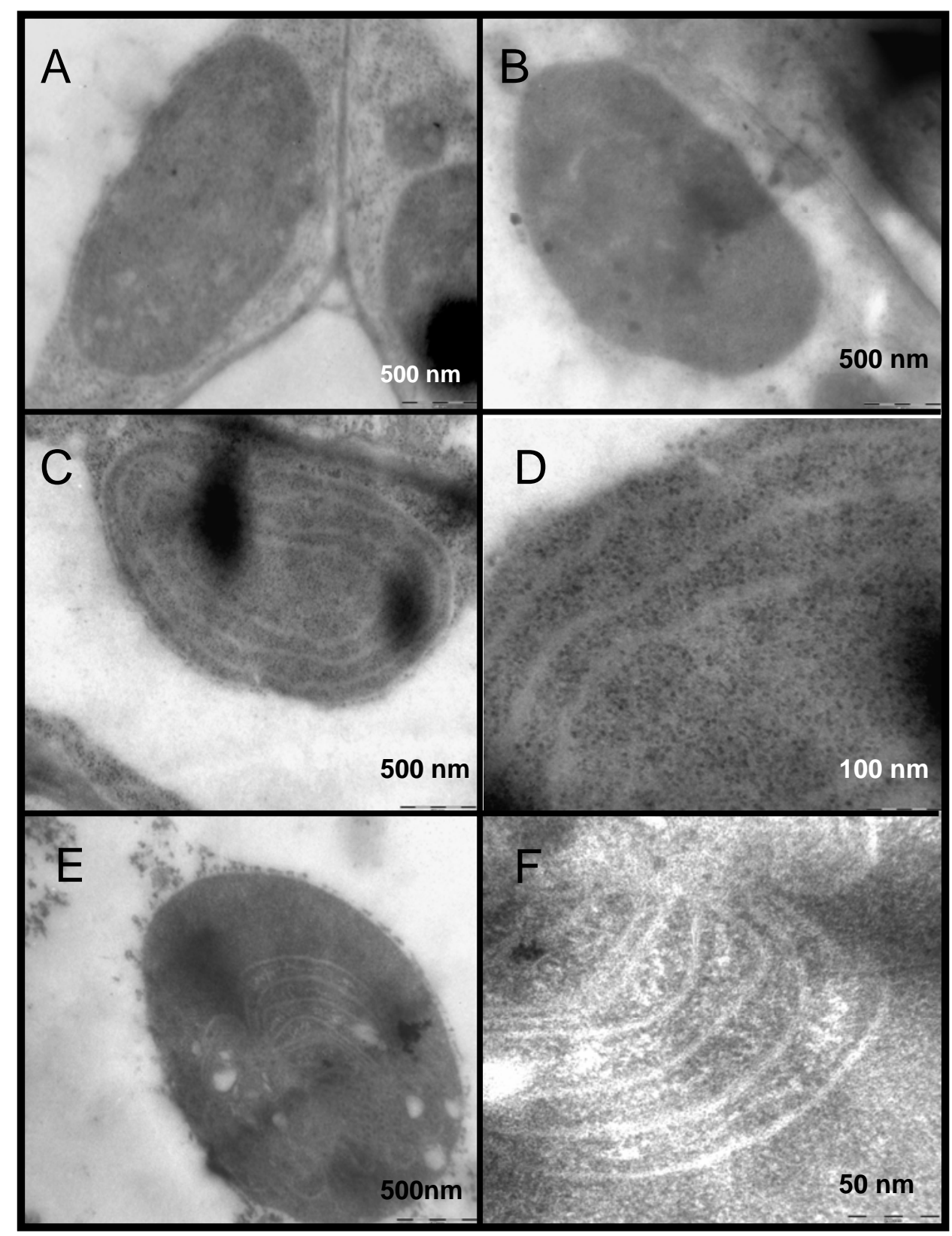

Figura 8 - Ultraestrutura dos plastídios de folhas de tabaco cultivados em meio de cultura MS com 3\% de sacarose e ausência de luz. Plantas selvagens WT (A e B); Transgênicas TR1 (C e D) e TR2 (E e F) 


\subsection{Avaliação da presença das proteínas Lhcb e D1 por Western Blot}

Essas proteínas foram escolhidas para sinalizar a formação estrutural das membranas dos tilacóides nos cloroplastos. Como já mencionado, o fotossistema II, é um complexo de pigmentos - proteínas com mais de 20 proteínas na membrana tilacóide, catalisa e dirige a luz para a oxidação da água e redução da plastoquinona.

A presença da proteína Lhcb indica que há expressão constitutiva do gene Lhcb 1*2 nos cloroplastos, por Western blot. As proteínas separadas em gel de poliacrilamida foram transferidas para a membrana de PVDF sobre a qual procederam-se as reações imunoquímicas. O primeiro anticorpo, específicas para a Lhcb, identifica uma seqüência de aminoácidos comuns (determinante antigênico), que reage com a proteína e revela resultado positivo.

Procedeu-se uma padronização na concentração protéica das amostras aplicadas no gel para a eletroforese, pois sem essa padronização há interferência nos resultados obtidos. Assim todos os poços estavam com o equivalentes à $3 \mu g$ de clorofila.

$\mathrm{Na}$ figura 9, observa-se a presença da proteína Lhcb em todos os genótipos após 6, 18 e 120 horas de iluminação. Já no tempo de 0 hora observa-se a detecção somente em TR-2. Nesse caso, genótipo transgênico apresenta um adiantamento na produção dessa proteína por expressar constitutivamente o gene Lhcb $1^{*} 2$, como citados por outros autores (Real, 1997; Pinto, 2000; Romano, 2001 e Brito, 2001) a introdução desse gene causou uma série de alterações nas plantas transgênicas, isso levou a concluir que estas plantas não estão obedecendo o ritmo circadiano de desenvolvimento das plantas, assim 
como também nesse estudo que mostrou uma adiantamento no desenvolvimento plastídial.

Já a proteína D1 compõe o centro de reação do PSII, esta é um heterodimero essencial na redução de componentes do PSII (clorofila a $\mathrm{P}_{680}$, feofitina, íons ferro e quinonas). Quando ocorre fotodanos ao PSII, um eficiente mecanismo de reparo envolve re-alocação da D1 e sintese de novas cópias (Zhang et al. 2002). A luz é um importante fator de regulação em vários estágios da sintese dessa proteína. Na figura 10 observa-se a analise de Western blot para a D1, onde em todos os momentos tem-se a proteína sendo esse pequeno no tempo de zero hora e evoluindo com o passar das horas, já com 18 horas há uma diminuição em decorrência do ritmo circadiano de desenvolvimento, voltando a crescer a quantidade com 120 horas.

Experimentos com plantas superiores tem revelado que, a iniciação da translação da D1 do núcleo para o cloroplasto e a elongação é estritamente regulado, não há acumulo da D1 em etioplastos, o gene psbA, que ativa o processo, é transcrito abundantemente e associados aos polisomos, com a iluminação ocorre a elongação da proteína e seu acumulo, concomitante com a síntese de outros pigmentos (Zhang et al. 2002). 

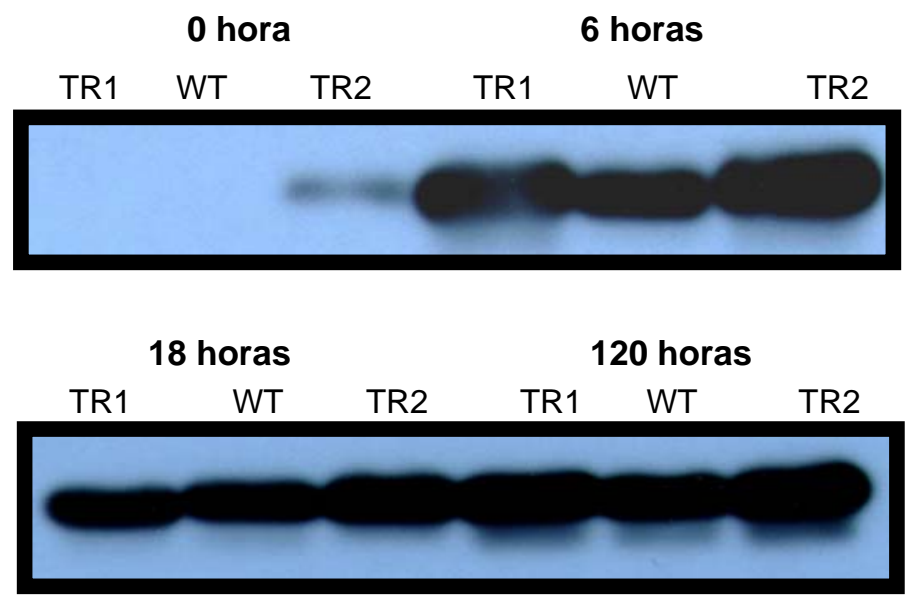

Figura 9 - Análise de Western blot das plântulas de tabaco (Nicotiana tabacum L.) para a deteç̧ão da proteína $\mathrm{CAB}$ "chlorophyl a/b binding protein" (Lhcb) do fotossistema II, através de anticorpo específico. As coletas foram realizadas após 0, 6, 18 e 120 horas de iluminação. As canaletas obedecem sempre a mesma ordem: TR1, WT e TR2 

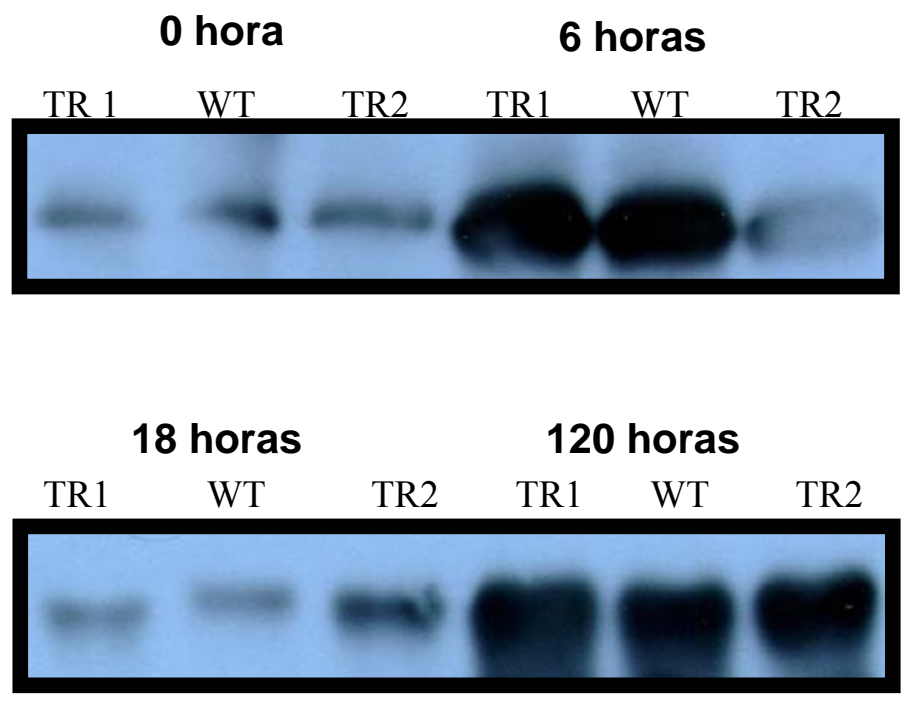

Figura 10 - Análise de Western blot das plântulas de tabaco (Nicotiana tabacum L.) para a detecção da proteína D1 do fotossistema II, através de anticorpo específico. As coletas foram realizadas após 0, 6, 18 e 120 horas de iluminação. As canaletas obedecem sempre a mesma ordem: TR1, WT e TR2 


\section{CONCLUSÕES}

A expressão constitutiva do gene $L h c b 1 * 2$ de ervilha, resultou em alterações morfológicas, fisiológicas e bioquímicas nos cloroplastos das plantas de tabaco.

- Há uma antecipação no desenvolvimento dos cloroplastos nos cotilédones das plantas transgênicas (TR1 e TR2) em relação ao que foi observado no material selvagem original (WTRS1).

- A formação da membrana dos tilacóides nas transgênicas já no início da iluminação é precoce, e ocorre mais rápido do que no selvagem.

- A presença da sacarose em meio como fonte de carboidrato não estimulou o desenvolvimento dos plastídios no material vegetal selvagem (WTRS1). Já para o caso dos transgênicos (TR1 e TR2), os plastídios estavam em uma fase mais adiantada, mesmo assim não se pode concluir que $\mathrm{o}$ fornecimento de carboidrato adianta o desenvolvimento plastídial.

- A presença de proteínas responsáveis pela formação do fotossistema II (CAB e D1), leva a concluir que a montagem do aparato fotossintético é adiantada nas linhagens transgênicas (TR1 e TR2) quando comparada ao mesmo estádio de desenvolvimento do selvagem (WTRS1). 


\section{REFERÊNCIAS BIBLIOGRÁFICAS}

ANDERSSON, B.; STYRING, S. Photosystem II: Molecular organisation, function and acclimation. In: KROGMANN, D. W. ED. Currents Topics in Bioenergetics, v.16, p. 2-81, 1991.

BASSI, R.; BARBATO, R.; HINZ, U. G. The role of the light harvesting complex and photossystem II in thylakoid stacking in the Chlorina f2 barley mutant. Carlberg Reserch Communication, v. 50, p. 347367.1985.

BASSI, R.; SANDONÀ, D.; CROCE, R. Novel aspects of chlorophyll a/b binding proteins. Physiologia Plantarum, v. 100, p.769-779, 1997.

BRITO, G. J. M. Estudos da assimilação de nitrato em plantas transgênicas de tabaco (Nicotiana tabacum L.) que expressam o gene Lhcb $1 * 2$ de ervilha constitutivamente. Piracicaba, 2001. 77p.Tese (Mestrado) - Escola Superior de Agricultura "Luiz de Queiroz" , Universidade de São Paulo.

CARVAlho, H. F.; ReCCO-PIMEnTEl, S. M. A Célula 2001. Campinas: UNICAMP, 2001. 287p. 
CLINE, K. , HENRY, R. Import and routing of nucleus-encoded chloroplasts proteins. Annual Review Cell Development Biology, v.12, p. 1-26. 1996.

COOPER, G. M. A Célula: uma abordagem molecular. Trad. de I. S. Vaz Júnior et al. $2^{0}$ ed. Porto Alegre: Artmed, 2001. 712 p.

DENT, R. M.; HAN, M.; NIYOGI, K.K. Functional genomics of plant photossynthesis in the fast lane using Chlamydomonas reinhardtii. Trends in Plant Science, v.6, n.8, p. 364-371, 2001.

GRAY, J. C.; SUlliVAN, J. A.; WANG, J.; JEROME, C. A., MACLEAN, D. Coordination of plastid and nucleai gene expression. Philosophical Transactions of the Royal Society of London. Series B, Biological Sciences, v.358, p. 135-145, 2002.

GREEN, B. R.;PICHERSKY, E.; KLOPPSTECH, K. Chlorophyll a/bbinding proteins: an extended family. Trends in Biochemical Sciences, v. 16, p. 181-186, 1991.

HANKAMER B. \& BARBER J. Structure and membrane organization of photosystem II in green plants. Annual Review of Plant Physiology and Plant Molecular Biology, v. 48. p. 641-671, 1997.

HORTON P.; RUBAN A. V.; WALTERS R. G. Regularion of light harvesting in green plants. Annual Review of Plant Physiology and Plant Molecular Biology, v. 47 p. 655-684, 1996. 
JANSSON S.; PICHERSKY E.; BASSI R.; GREEN B. R.; IKEUCHI M.; MELLIS A.; SIMPSON D. J.; SPANGFORT M.; STAEHELIN L. A. AND THORNBER J. P. A nomenclature for the genes encoding the chlorophyll a/b binding proteins of higher plants. Plant Molecular Biology Repórter, v. 10 p. 242-253. 1992.

JARVIS, P.; DORMANN, P.; PETO, C.A.;LUTES, J.; BENNING， C. \& CHORY, J. Galactolipid deficiency and abnormal chloroplast development in the Arabidopsis MGD syntetase 1 mutant. Proceedings of the National Academy of Science, v.97, n. 14, p.8175-8179, 2000.

KO, K.; KO, Z. W.; TURPIN, D. H.; LABATE, C. A.; MOHANTY, N.; GRANELL, A. Overproduction of chlorophyll $\mathrm{a} / \mathrm{b}$ binding protein enhances photosyntetic actvity in transgenic tobacco. In: MURATA, N. (Ed.) Research in photosynthesis. Netherlnds: Kluwer Academic, 1992. cap. 3, p. 445-448.

KROLL, D.; MEIERHOFF, K.; BECHTOLD, N.; KINOSHITA, M.; WESTPHAL, S.; VOTHKNECHT, J. S. \& WESTHOFF, P. VIPP1, a nuclear gene of Arabidopsis thaliana essential for thylakoid menbrane formation. Proceedings of the National Academy of Science, v.98, n. 7, p.4238-4242, 2001.

KÜHLBRANDT W.; WANG D. N.; FUJIYOSHI Y. Atomic model of plant light-harvesting complex. Nature, v. 367, p. 614-621, 1994. 
LABATE, C. A. Efeitos pleiotrópicos da expressão constitutiva do gene Lhcb 1*2 de ervilha em plantas transgênicas de tabaco (Nicotiana tabacum) e petúnia (Petunia hybrida). Piracicaba, 2001. 119p.Tese (Livre-Docência) - Escola Superior de Agricultura “ Luiz de Queiroz” , Universidade de São Paulo.

MITRA, S.; BHARDWAJ, S. N.; SRIVASTAVA, G. C. Source and sink relationship. In: ABROL, Y. P.; GOVINDJEE (Ed.). Photosynthesis: photoreactions to plant productivity. London: Academic Press, 1993. cap. 25, p. 361-387.

MURASHIGE, T.; SKOOG, F. A revised medium for rapid growth na bioassays with tobaco tissue cultures. Physiologia Plantarum, v. 15, n. 3, p.473-497, 1962.

PIMENTEL, C. Metabolismo de carbono na agricultura tropical. Seropédica: Edur, 1998. 159p.

PINTO, L. S. R. C. Avaliação do metabolismo fotossintético de plantas transgênicas de tabaco (Nicotiana tabacum) que expressam o gene Lhcb 1*2 constitutivamente em condições de alta luminosidade. Piracicaba, 2000. 140p.Tese (Doutorado) - Escola Superior de Agricultura “Luiz de Queiroz”, Universidade de São Paulo.

REAL M. J. U. D. Efeito do aumento do complexo protéico clorofila a/b no metabolismo fotossintético de plantas transgênicas de tabaco (Nicotiana tabacum L.). Piracicaba, 1997. 150p.Tese (Doutorado) Escola Superior de Agricultura “Luiz de Queiroz", Universidade de São Paulo. 
ROMANO, M. R. Análise de crescimento, produção de biomassa, fotossintese e biossintese de aminoácidos em plantas transgênicas de tabaco (Nicotiana tabacum L.) que expressam o gene Lhcb $1 * 2$ de ervilha. Piracicaba, 2001. 66p.Tese (Mestrado) - Escola Superior de Agricultura "Luiz de Queiroz", Universidade de São Paulo.

SIMIDJIEV, S; STOYLOVA, H.; AMENITSCH, R.; JAVORFI, L.; MUSTARDY, P.; LAGGNER, A \& HOLZENBURG, G. Self-assembly of large, ordered lamellae from non-bilayer lipids and integral membrane proteins in vitro. Proceedings of the National Academy of Science, v.97, n. 4, p.1473-1476, 2000.

SPURR, A. R. A. Low-viscosity epoxy resin embedding medium for electron microscopy. Journal of Ultrastructura Research, New York, v. 26, p.31-43. 1969.

THORNBER, J. P. Biochemical characterization and structure of pigment-proteins of photosynthetic organisms. In: STAEHELIN, C. J.; ARNTZEN, C. J. (Ed.) Encyclopediaa of Plant Physiology: Photosynthesis III; photosynthetic membranes and light havesting systems. Berlin: Springer - Verlag, 1996. cap. 19, p. 98-142.

TOWBIN, H.; STAEHLIN, T.; GORDON, J. Eletroforetic transfer of proteins from polyacrylamide gels to nitrocellulose sheets procedure and sample application. Proceedings of the National Academy of Science, v.77, n. 14, p.4350-4354, 1979.

VOTHKNECHT, U. C. ; WESTHOFF, P. Biogenesis and origin of thylakoid membranes. Biochemistry Biophysics Acta, v.1541, p. 91-101, 2001. 
WAN, J.; BRINGLOE, D.; LAMPPA, G. K. Disruption of chloroplast biogenesis and development upon down-regulation of chloroplast processing enzyme involved in the import pathway. Plant Journal, v. 15 , p. $459-468,1998$.

WESTPHAL, S.; HEINS, L.; SOLL, J. ; VOTHKNECHT, U. C. Vipp1 deletion mutant of Synechocystis: Proceedings of the National Academy of Science, v.98, n. 7, p.4243-4248, 2001.

WetTSTEIN, D.; GOUGH, S.; KANNANGARA, C. G. Chlorophyll Biogenesis. The Plant Cell, v. 7, p. 1039-1057. 1995.

WETTSTEIN, D.V. Discovery of a protein required for photosynthetic membrane assembly. Proceedings of the National Academy of Science, v.98, n. 7, p.3633-3635, 2001.

WILLEY, D. L.; GRAY, J. C. Synthesis and assembly of cytocrome b6- $f$ complex in higher plants. In: GOVINDJEE, BOHNERT, H. J.; BOTTOMLEY, W.; BRYANT, D. A.; MULLET, J. E.; OGREN, W. L.; PAKRASI, H.; SOMERVILLE, C. R. (Ed.). Molecular Biology of Photosynthesis, Oxford: Press at Oxford University Press, 1998. cap. 15 , p. $497-516$.

WOLLMAN, F.; MINAI, L. ; NECHUSHTAI, R. The biogenesis and assembly of photosynthetic proteins in thylakoid membranes. Biochemistry Biophysics Acta, v. 1411, p. 21-85, 1999.

ZHANG, L. ; ARO, E. Syntesis, membrana insertion and assembly of chloroplast-encoded D1 pretein into photosystem II. FEBS Letters, v. 512 , p. $13-18,2002$. 